\title{
Musi River Pollution Its Impact on Health and Economic Conditions of Down Stream Villages-A Study
}

\author{
Dr.Pullaiah Cheepi \\ Department of Economics, Osmania University, Andhra Pradesh, India.
}

\begin{abstract}
Hyderabad is the $5^{\text {th }}$ largest city in India. It has twin cities Viz., Hyderabad and Secunderabad with its suburbs extending up to 16 miles. The core cities, together with its nine surrounding municipalities are covering an area of 500 square $\mathrm{km}$. The Hyderabad city discharges about 600 million liters per day untreated sewerage water into Musi River. The drinking water in entire area is brought from distant places; they were spending lots of money. There are at least 30 villages with a population of 1.00 .000 that are directly affected in this region. The quality of water in Musi is beyond description. The economic impact and the problems created by the pollution is under taken with reference to sample households, the impact is studied under five sections, 1) This section purely scientific tests were conducted for four sample villages, that are Physical, Chemical and Bacteriological water quality parameters are briefly explained through the water sample reports (Institute of Preventive Medicine Hyderabad Andhra Pradesh). 2) Availability and impact of water cost of the selected sample villages. 3) Health problems caused by pollution and medical expenses incurred by sample households. 4) Water pollution affect on the cattle and fish population.
\end{abstract}

5)Water pollution effects on the traditional occupations .

Keywords: Water pollution, Industrial pollution, Biological Oxygen Demand, Chemically Oxygen Demand, health expenditure, health hazards, health problems.

\section{Introduction}

Water is the most important natural resource and essential for life, as it provides habitat for diverse type's of aquatic life in rivers, lakes and oceans and makes $65 \%$ of human body. The great historical cities grew around rivers and lakes because of human dependence on water. The expansion of agriculture and industrial development has not only increased water consumption considerably but has also affected water quality. Water is easily polluted because of its great ability to dissolve substances. Even before raindrops touch the earth, they stand picking up pollutants. Once on the ground, water picks up things rapidly, and becomes contaminated. The various human activities and industries not only require water in large amounts, they also pollute it while using it. Apart from industries, water is polluted by agricultural and domestic or municipal sources. The water pollutants vary in nature; they include biological agents, chemicals that make water rich in nutrients, chemicals that poison water sediments, heat and radioactive waste. Nearly all water bodies are affected by pollution, including ground water. In many developed countries, water pollution is a major problem and many river basins have been found to show high organic matter concentration (UNEP/GEMS1995). Polluted water loses its economic and aesthetic value. Over the years, water pollution has emerged as an important issue in India as most of the rivers are polluted, which are having substantial negative impact on human health and aquatic life. The varieties of fish grown in a sewage pond would need to change if the quality deteriorated, and fishing would have to be stopped entirely if the water quality deteriorated substantially. Health problems can ensue for agricultural workers due to pathogenic bacteria, viruses and parasites present in the wastewater as well as for consumers of wastewater-irrigated produce particularly if the produce is not cooked before it is consumed. Hookworm infections are more common in agricultural workers who go barefoot in wastewater- irrigated fields (van der Hoek et al, 2002).

\section{Methodology}

There are more than 50 villages that are affected in downstream of Musi River. We propose to take four villages, one at head reach, second at middle reach, third and fourth at the tail-end. We propose to study the impact in four villages namely, Pratapa Singaram (located $15 \mathrm{Km}$ away from Amber Pet Treatment Plant), Enkiryal (30 Km away from Amber Pet Treatment Plant), Surapally (45 Km away from Amber Pet Treatment Plant), and Aroor (60 Km away from Amber Pet Treatment Plant) The Four villages, besides distance being a factor, are prominent for three different activities such as agriculture, handloom industry and other nonagricultural activities like diary.

The social costs of pollution related damage in the villages in downstream villages of Musi have to be estimated comprehensively. This includes value of loss in agriculture, damage to agricultural land, cost due to loss of cattle and other livestock, cost of health hazard, loss of employment and loss of livelihood due to 
pollution. The impact of pollution can be direct such as, fall in the agricultural yield, rise in input costs for agriculture, rise on input costs for cottage industries, like handlooms, to allied products like dairy, poultry, livestock, toddy, village services such as washing clothes, etc.

\section{Water Quality Parameters In Sample Villages}

In this study, four downstream villages were covered for every 15 K.M respectively of the downstream of the Musi river basin. They are,

Station-I: $\quad$ Pratap Singaram, which belongs to the Ghatkesar MandalRanga Reddy District, A.P, India

Station-II: $\quad$ Enkirayal, which belongs to the Bibi Nagar Mandal, Nalgonda District, A.P, India

Station-III: $\quad$ Surapally village, Bhuvanagiri Mandal, Nalgonda District A.P, India

Station-IV: $\quad$ Aroor village, Valigonda Mandal, Nalgonda District. Out of these, only Pratap Singaram comes under Ranga Reddy district and the other three come under Nalgonda district. A.P, India

\section{Physical Properties}

In the area under investigation physical characters like color, taste, odor, turbidity and temperature are the main physical qualities to be considered for water for beneficially use. Some of the physical qualities may be critical to restrict the usability of water for specified purpose. It is, therefore, in the present investigations, color, odour, temperature, turbidity and taste of all the ground water samples noted while collecting the water samples .Physical parameters of water samples of the 4 stations with $15 \mathrm{Km}$. intervals are as follows.

\section{Colour and Odor}

Colour and odor have no direct chemical significance but indicate quality or pollution. Dark brown or yellowish water usually contains tannins and other vegetable chemicals, sediments usually cause reddish colors. True color is due to dissolved materials and apparel; color is due to turbidity or suspended particles. Filtration is used to distinguish between the colors. Pure water does not have odor or taste $\mathbf{p H}$

The concentration of hydrogen ion is known as the $\mathrm{pH}$. The negative logarithm or the hydrogen ion concentration is an important characteristic of water. $\mathrm{pH}$ influences dissolution and precipitation and determines whether and what aquatic life is possible. The $\mathrm{pH}$ value of water is an important index of alkalinity or acidity and is the resulting value of acidic/ basic interaction of number of its mineral and organic compounds. It is expressed as a given temperature. The value of 6.5 to $9.2 \mathrm{pH}$ value is the maximum permissible limits for domestic use (WHO 1971) while the $\mathrm{pH}$ value of 4.5 to $9 / 0$ in general agreeable for irrigation. Table No- 1 The $\mathrm{pH}$ of the water of the study of four stations are falling between 8.26 to 7.51 even the samples are not with in normal range. Hence they are not suitable to be consumed as drinking water, why because due to the industrial effluents, the $\mathrm{pH}$ is also altering with the different time intervals at the same stations.

\section{Turbidity}

Non-polluted water is clear and gain very less turbidity, due to the suspended particles of mud and some minerals, but polluted water is very turbid and they gain the dark coloration also. Table No-1 shows the turbidity and colour is slightly varying in four stations according to the release of industrial effluents

\section{Specific Electrical Conductance}

The term specific electrical conductance denotes the characteristics of a medium to the passage of electricity. Specific Conductance of water is reciprocal of the resistance and is commonly represented in $\mu$ Siemens $/ \mathrm{cm}$. Specific Conductance is used as a measure of the quality of water as it facilitates quick determination of total dissolved solids in water. As it varies with the temperature it is represented at standard temperature of 25 degree $\mathrm{C}$. The relationship of dissolved solids to conductance becomes indefinite for waters very high in dissolved solids. Table No-1 shows the Electrical Conductivity at 25 degree $\mathrm{C}$ is normal range is 750 , but in it is more than normal range in four stations 1010, 1250,1360, 1310 respectively so this indicates that water salinity is high because of the high TDS, and TSS,. So this indicates the water in not suitable for direct consumption and different components are responsible for the different types of the health hazards. Like diarrhea, joint pains, skin allergies, gastrointestinal disturbances, and vomiting. These symptoms also persist even by the consumption of agriculture productivity of those areas.

\section{Total Dissolved Solids}

Total dissolved solids can be determined quickly by measuring the Electrical conductance of water samples or by evaporation of filtered samples of water and weighing the residue. Bicarbonates, sulphates and chlorides of calcium, magnesium, sodium constitute the major part of the total dissolved solids. Where as potassium, chloride nitrate, and boron from a minor part of the total dissolved solids. There are at least three commonly used units for dissolved solids: 1 .concentration in $\mathrm{mg} / \mathrm{L}$, 2. salinity in parts per thousand or the equivalent, grams solids per kilogram water, $\mathrm{g} / \mathrm{kg}$. and, 3. density in grams per cubic meter. Concentration in 
milligram per liter is nearly equal to parts per million, PPM, up to a concentration of $7000 \mathrm{mg} / \mathrm{L}$. Below is an equation for relating temperature' and salt content, $\mathrm{g} / \mathrm{kg}$, to the density of water in $\mathrm{kg}$ per cubic meter. Total dissolved solids (TDS) are determined in the lab by evaporation of a filtered sample to obtain the residue whose weight is taken and divided by the sample volume. When reporting the results of an analysis it is important to report the drying temperature. The four stations it is varying from 2050, 810, 920, 830mg/l , station -I Pratapa singaram is near to the Hyderabad industrial area, it receives the large number of industrial effluents which were exhibited directly through the influence of the water samples. The details are given in the table no: 1 .

\section{Total Hardness}

Hardness is one of the important Hydro geochemical characteristics to determine the suitability of water for domestic drinking and industrial purposes. Hardness is caused principally due to the dissolved contents of carbonates and sulphates of calcium and magnesium; At times to a lesser degree, presence of chlorides, nitrates and sometimes iron and aluminum is effective in causing hardness. It is expressed as ppm in terms of calcium carbonate. Table No-1 shows the results of Total Hardness in four stations which are 248, 312, 308,306 respectively it has rapidly increased from station-I, to station II, then other two stations have slightly decrease. High quantity of Calcium in water is one of cause for gastrointestinal disturbances and increased kidney stone problems in the people who consumed that water.

\section{Total Alkalinity}

Total alkalinity is caused due to the presence of carbonates, bicarbonates and hydroxides of calcium, magnesium, potassium and sodium. Calcium is the most common constituent that causes alkalinity. Generally total alkalinity expressed as $\mathrm{CaCO}$. Carbonates and Bicarbonates of calcium and magnesium not only contribute to Total alkalinity but also to temporary hardness. When the total hardness and total alkalinity is equal all the hardness is termed as carbonate hardness. If the total hardness exceeds the total alkalinity, the excess represents non-carbonate hardness. Some times the total hardness is less than total alkalinity then the difference indicates the presence of sodium bicarbonate, which adds to the alkalinity but does not increase the hardness. Table No-1 in four stations it is gradually decreased from 324 to 112 , which is varying for the normal range of 200 as for (PHEEO). It also influences the soil fertility. Excess Alkalinity in water is not good to consume and relatively not better and can cause gastrointestinal.

\section{Calcium}

Calcium is an important constituent of number of minerals. The excess presence of Calcium in water samples is associated with hardness of water. The elemental calcium is an important component for the bone formation etc..., but the excess presence shows the harmful impact on the health. The permissible limit is according to WHO $75 \mathrm{mg} / \mathrm{l}$, Table No-1 shows the four stations $160,176,172$, and $174 \mathrm{mg} / \mathrm{l}$ respectively, so this indicates hardness of the water for four stations, which are not suitable for the regular usages after hardness effects the fertility of the soil. High level of Calcium in water will be deposited more in kidney stones.

\section{Chlorides}

In natural water chloride occurs in widely varying concentration. Abnormal chloride concentration may result due to pollution of sewerage waste and leaching of saline residues in the soil. Its desirable limit is 200-250 $\mathrm{mg} / \mathrm{L}$ beyond this limits, taste, corrosion and palatability are affected; and deficiency of chloride also influence of the productivity of the agriculture. Less availability of the sodium chloride in cattle leads to decrease the lactation and chloride deficiency of calf leads decrease in body weight nerve system abnormalities. Table No-1 shows that the chloride levels in four stations rapidly increase from station-I 148, to station IV, 212. It indicates that excess presence of Chlorine in water leads to gastrointestinal, diarrheic, and skin allergies.

\section{Sulphates}

Through the Sulphate concentration of atmospheric precipitation is only about $2 \mathrm{ppm}$, but in different water bodies the sulphate concentration varies widely due to oxidation, and precipitation processes as the water traverses, through the rocks. Sulphates are an important contents in proteins and amino acids. In nature sulphate is available in the form of sulphates, sulphars, sulphades, autotrophic plants are ready to dissolve the sulphates if the sulphades joins along with iron and forms ferrous sulphide. If they are oxidized they produce ferros sulphate acid, by the human interception sulpheric acid and other sulphate compounds responsible for the increase of acid nature of water bodies which is harmful to aquatic organism. Table No-1 shows that sulphate levels have decline from station- I to station-II then station-III and station-IV are slightly decline. The abnormal presence of Sulphates induces the formation of sulphuric acid, Hyderozen sulphate, its man may be a cause for the gastrointestinal and skin allergies. 
Floride

One of the serious problems of excessive amount of fluoride in waters is "Flourosis", which affects the bones and teeth, and prevails in the areas having fluorine content more than $1.5 \mathrm{ppm}$ in drinking waters of fluoride. The above permissible limits for drinking water ranging in concentrations from 1.56, flourosis induces serve joint pains, in adults and bone deformation decay of teeth etc..., in children.

Nitrate

Due to the rapid growth in the area of irrigated land, modern and improved agricultural practices have increased many folds. The use and applications of $\mathrm{N}$ - fertilizers and pesticides by the farmers to achieve the maximum production of crops, has become the main threat to the ground water quality. Another important source of nitrate pollution is human and animal excreta and decomposition of organic matter in soil. High concentrations i.e. more than $45 \mathrm{ppm}$ in drinking waters is relatively toxic to human and can result infertile methemoglobinamia or cyanosis, which reduces the capability of blood to carry oxygen to the body tissues .In Table No-1 Nitrate levels are gradually decline from station-I to station-IV that is $81 \mathrm{mg} / \mathrm{l}$ to $74 \mathrm{mg} / \mathrm{l}$. The excess level of nitrates induces the methmoglobia, in aquatic animals like fishes, but the symptoms may also develop in the people who consume fishes; the cattle may be also affected by drinking of that water.

\section{Ammoniac Nitrogen}

Nitrogen exists in nature in many different forms and there are reactions commonly that go by different forms. 'Nitrification, the oxidation of ammonia and nitrite to nitrate, consumes oxygen in the water column and streambed- Ammonia and nitrate are also important nutrients for the growth of algae and other plants like pistia and icornia. Excessive nitrogen can lead to Eutrophication. In the process of Eutrophication due to high availability of nutrients producers like algae and other plants rapidly grow, in large numbers, at the same time the dependent aquatic animals or consumers also rapidly increases. The mismatch between the requirement of more oxygen for consumption, finally due to high BOD requirement, less oxygen availability leads to death of the aquatic fauna. In Table No-1 Ammonic Nitrogen levels appeared in station-I only. Remaining all three stations are nil in the levels of Ammonical Nitorgen. The Ammonical Nitrogen increases the yielding rate of agriculture and paragrass, but those products also receive other types of harmful chemical components, which were not found in natural cultivation. Those products are very rich in colorization and appearance, but they contain harmful chemicals, and those who consume are affected by gastrointestinal, joint pains, liver infection, jaundice and kidney infection. The Para grass consumed cattle are good accordingly to appearance, but they suffer with the joint problems, infection in kidney, liver spleen and gonads. These cattle are prone to abortions and they are observed deceased productivity of milk yielding.

\section{Biological Oxygen Demand (Bod) and Chemically Oxygen Demand (COD)}

BOD is the amount of oxygen consumed by microorganism while stabilizing or degrading, carbonaceous and nitrogenous compounds under aerobic conditions. The BOD test is used to indicate the strength of wastes in the water and is used to protect aquatic life from oxygen tendency. It is a regulatory tool. Oxygen is added to water by diffusion from atmosphere and photosynthetic activity of green plants. The amount of dissolved oxygen in water is an indicator of its quality and the kind of life it can support. Water with dissolved oxygen content of $8 \mathrm{mg} / \mathrm{l}$ can support many fish and other desirable forms of aquatic life. Water with dissolved oxygen content of $2 \mathrm{mg} / \mathrm{l}$ can only support worms, bacteria and other decomposers. The primary source of organic matter in lakes and rivers is waste water from industrial effluents and domestic sewage. Pollution load due to sewage or other organic wastes is measured in terms of their Biological Oxygen Demand. BOD of clean fresh water is $2 \mathrm{mg} / \mathrm{l}$, whereas values exceeding $5 \mathrm{mg} / \mathrm{l}$ indicate pollution. Several factors affect BOD. Cool water dissolves more oxygen and, in it the rate of decomposition of organic matter is slower than in warm water. The dissolved oxygen should not drop below 3ppm at any time; in fact should remain above 5ppm for a normal health of an aquatic system. In Table No-1 shows the levels of BOD gradually decline from stationI to station-IV that is $16 \mathrm{mg} / \mathrm{l}$ to $4 \mathrm{mg} / \mathrm{l}$. The COD test measures the total quantity of oxygen required 'or oxidation of a waste to carbon dioxide and water. It is sometimes used as an approximation 'or the BOD test as the COD test can be ran in 3 hours instead of the 5 days required for the 30D test. The COD test does not distinguish between biologically degradable and biologically refractory, orbiodegradable, material. Table No -2 shows that COD level is very high in station-I, $128 \mathrm{mg} / \mathrm{l}$, then it rapidly decline by the four folds in station -II , then two folds decline in station III, and station-IV is noted. 
Musi River Pollution Its Impact On Health And Economic Conditions Of Down Stream Villages-A

Table-1 Water Quality Parameters in Musi River Down Steam Villages

\begin{tabular}{|c|c|c|c|c|c|}
\hline Parameters & $\begin{array}{l}\text { Pratapa } \\
\text { Singaram }\end{array}$ & Enkirayala & Surapally & Aroor & $\begin{array}{l}\text { Water quality } \\
\text { Standers }\end{array}$ \\
\hline $\mathrm{pH}$ at $16.9^{\circ} \mathrm{c}$ & 8.29 & 8.63 & 7.84 & 7.51 & 7.0 to 8.5 \\
\hline TSS & $30 \mathrm{mg} / \mathrm{L}$ & $15 \mathrm{mg} / \mathrm{L}$ & $10 \mathrm{mg} / \mathrm{L}$ & $8 \mathrm{mg} / \mathrm{L}$ & \\
\hline TDS & $2050 \mathrm{mg} / \mathrm{L}$ & $810 \mathrm{mg} / \mathrm{L}$ & $920 \mathrm{mg} / \mathrm{L}$ & $830 \mathrm{mg} / \mathrm{L}$ & $500 \mathrm{mg} / \mathrm{L}$ \\
\hline B.O.D & $\begin{array}{l}\text { 3days at } 27 \\
\mathrm{c}^{\circ}-16 \mathrm{mg} / \mathrm{L}\end{array}$ & $\begin{array}{l}\text { 3days at } 27 \\
c^{\circ}-9.5 \mathrm{mg} / \mathrm{L}\end{array}$ & $\begin{array}{l}\text { 3days at } 27 \\
\mathrm{c}^{\mathrm{o}} 2.4 \mathrm{mg} / \mathrm{L}\end{array}$ & $\begin{array}{llll}\begin{array}{l}\text { 3days } \\
\mathrm{mg} / \mathrm{L}\end{array} & \text { at } & 27 & \mathrm{c}^{\mathrm{o}} \\
\end{array}$ & $3 \mathrm{mg} / \mathrm{L}$ \\
\hline C.O.D & $128 \mathrm{mg} / \mathrm{L}$ & $32 \mathrm{mg} / \mathrm{L}$ & $16 \mathrm{mg} / \mathrm{L}$ & $12 \mathrm{mg} / \mathrm{L}$ & $3 \mathrm{mg} / \mathrm{L}$ \\
\hline Color (H.U) & 60 & 60 & 70 & 65 & \\
\hline Turbidity & 24.4 & 23.1 & 30 & 25 & \\
\hline Odour & $\begin{array}{l}\text { Un- } \\
\text { objectionable }\end{array}$ & $\begin{array}{l}\text { Un- } \\
\text { objectionable }\end{array}$ & $\begin{array}{l}\text { Un- } \\
\text { objectionable }\end{array}$ & Un-objectionable & \\
\hline $\mathrm{pH}$ at $\mathrm{c}^{\mathrm{o}}$ & 7.55 & 8.48 & 7.46 & 7.51 & \\
\hline $\begin{array}{l}\text { Electrical } \\
\text { conductivity } \\
\text { at } 25 \mathrm{c}^{\mathrm{o}}\end{array}$ & 1110 & 1250 & 1360 & 1310 & 750 \\
\hline Alkalinity & 324 & 296 & 138 & 112 & 200 \\
\hline $\begin{array}{l}\text { Total } \\
\text { hardiness }\end{array}$ & 248 & 312 & 308 & 306 & 100 \\
\hline $\begin{array}{l}\text { Calcium } \\
\text { hardness }\end{array}$ & $160 \mathrm{mg} / \mathrm{L}$ & $176 \mathrm{mg} / \mathrm{L}$ & $172 \mathrm{mg} / \mathrm{L}$ & $174 \mathrm{mg} / \mathrm{L}$ & $75 \mathrm{mg} / \mathrm{L}$ \\
\hline $\begin{array}{l}\text { Ammonical } \\
\text { nitrozen }\end{array}$ & 1.5 & Nil & Nil & Nil & 1.2 \\
\hline Nitrite & Nil & 0.005 & $>1.0$ & $>1.2$ & \\
\hline Nitrate & $81 \mathrm{~g} / 1$ & $77 \mathrm{~g} / 1$ & $77 \mathrm{~g} / \mathrm{l}$ & $74 \mathrm{~g} / 1$ & $45 \mathrm{~g} / 1$ \\
\hline Sulphate & 80 & 46 & 16 & 18 & $200 \mathrm{mg} / \mathrm{L}$ \\
\hline Chloride & 148 & 232 & 208 & 212 & $200 \mathrm{mg} / \mathrm{L}$ \\
\hline Fluoride & 0.5 & 0.7 & 0.7 & 0.9 & $\begin{array}{l}0.156- \\
0.303 \mathrm{mg} / \mathrm{l}\end{array}$ \\
\hline Iron $(\mathrm{Fe})$ & Nil & Nil & Nil & Nil & 0.3 \\
\hline
\end{tabular}

Source: Test conducted on 18-11-2008, at (IPM)

Table-2 Report Of Bacteriological Analysis Of Water

\begin{tabular}{|l|l|l|l|l|}
\hline & $\begin{array}{l}\text { Pratapa } \\
\text { Singaram }\end{array}$ & Enkirayala & Surapally & Aroor \\
\hline $\begin{array}{l}\text { Residual chorine } \\
\text { mg per liter }\end{array}$ & - & - & - & - \\
\hline $\begin{array}{l}\text { MPN of Coliform } \\
\text { Bacteria per 100ml }\end{array}$ & $\geq 1609$ & $\geq 1609$ & $\geq 1609$ & $\geq 1609$ \\
\hline $\begin{array}{l}\text { Nature of Coliform } \\
\text { Bacteria isolated }\end{array}$ & E.Coli & E.Coli & E.Coli & E.Coli \\
\hline $\begin{array}{l}\text { MPN of each } \\
\text { Coliform }\end{array}$ & 9 & 9 & 9 & 9 \\
\hline
\end{tabular}

Source: Ch. Pullaiah Test was conducted on 18-11-2008 (IPM)

Table no:2 Shows the Bacteriological analysis shows the Coli form or E-coli levels are more than the permissible limits, which are indicates that gastroenteritis, skin diseases and other diseases, due to viruses and bacteria like malaria, typhoid, jaundice, etc are immediately known through quick manifestation. This analysis and the household survey data both have shown the high level of diseases are affected by the human beings and also the all the other living organisms. The water becomes unfit for drinking, the buffaloes, drinking the water stated getting diseases. This water is favorable for the growth of mosquitoes which are vectors for the malaria parasite plasmodia. If disinfected, coli form count in any sample of $100 \mathrm{ml}$ should be zero (WHO1971). 
Musi River Pollution Its Impact On Health And Economic Conditions Of Down Stream Villages-A

Table 3: Purpose Wise Purchase of Water and Cost of the Water by the Respondents in Pratapa Singaram Enkiryal Surapally and Aroor.

\begin{tabular}{|c|c|c|c|c|c|c|c|c|c|c|c|c|c|}
\hline \multirow[b]{2}{*}{$\begin{array}{l}\text { Name of } \\
\text { the } \\
\text { Village }\end{array}$} & \multirow[b]{2}{*}{ S.H.H } & \multicolumn{2}{|c|}{ Purchased water } & \multicolumn{3}{|c|}{ Water Cost } & \multicolumn{7}{|c|}{ Not Purchased } \\
\hline & & $\begin{array}{l}\text { Drink } \\
\text { Ing }\end{array}$ & $\begin{array}{l}\text { Cook } \\
\text { ing }\end{array}$ & Quantity & \begin{tabular}{|l} 
Price \\
$(20)$ \\
liters
\end{tabular} & $\begin{array}{l}\text { Annual } \\
\text { Expend. }\end{array}$ & $\begin{array}{l}\text { Drink } \\
\text { Ing }\end{array}$ & $\begin{array}{l}\text { Cook } \\
\text { ing }\end{array}$ & $\begin{array}{l}\text { Bath } \\
\text { Ing }\end{array}$ & $\begin{array}{l}\text { Wash } \\
\text { Ing }\end{array}$ & $\begin{array}{l}\text { Clean } \\
\text { Ing }\end{array}$ & $\begin{array}{l}\text { Live } \\
\text { Stock }\end{array}$ & Others \\
\hline $\begin{array}{l}\text { Pratap } \\
\text { singrm }\end{array}$ & 45 & $\begin{array}{l}03 \\
(6.60)\end{array}$ & $\cdots$ & 20 & 10 & 10,800 & $\begin{array}{l}42 \\
(93.33)\end{array}$ & $\begin{array}{l}45 \\
(100)\end{array}$ & $\begin{array}{l}45 \\
(100)\end{array}$ & $\begin{array}{l}45 \\
(100)\end{array}$ & $\begin{array}{l}45 \\
(100)\end{array}$ & $\begin{array}{l}45 \\
(100)\end{array}$ & $\begin{array}{l}45 \\
(100)\end{array}$ \\
\hline Enkiryal & 92 & $\begin{array}{l}83 \\
(90.21)\end{array}$ & $\begin{array}{l}0 \\
(21.73)\end{array}$ & 20 & 3 & 79,640 & $\begin{array}{l}99 \\
(9.78) \\
\end{array}$ & $\begin{array}{l}72 \\
(78.26)\end{array}$ & $\begin{array}{l}92 \\
(100)\end{array}$ & $\begin{array}{l}92 \\
(100)\end{array}$ & $\begin{array}{l}92 \\
(100) \\
\end{array}$ & $\begin{array}{l}92 \\
(100)\end{array}$ & $\begin{array}{l}92 \\
(100)\end{array}$ \\
\hline Surapally & 47 & $\begin{array}{l}41 \\
(87.22)\end{array}$ & $\begin{array}{l}9 \\
(19.14)\end{array}$ & 20 & 4 & 63,360 & $\begin{array}{l}6 \\
(12.76)\end{array}$ & $\begin{array}{l}38 \\
(8.85)\end{array}$ & $\begin{array}{l}47 \\
(100)\end{array}$ & $\begin{array}{l}47 \\
(100)\end{array}$ & $\begin{array}{l}47 \\
(100)\end{array}$ & $\begin{array}{l}47 \\
(100)\end{array}$ & $\begin{array}{l}47 \\
(100)\end{array}$ \\
\hline Aroor & 56 & $\begin{array}{l}47 \\
(83.92)\end{array}$ & $\begin{array}{l}7 \\
(12.5)\end{array}$ & 20 & 10 & $1,69,200$ & $\begin{array}{l}9 \\
(16.0)\end{array}$ & $\begin{array}{l}49 \\
(87.5)\end{array}$ & $\begin{array}{l}56 \\
(100) \\
\end{array}$ & $\begin{array}{l}56 \\
(100)\end{array}$ & $\begin{array}{l}56 \\
(100)\end{array}$ & $\begin{array}{l}56 \\
(100)\end{array}$ & $\begin{array}{l}56 \\
(100)\end{array}$ \\
\hline Total & 240 & $\begin{array}{l}174 \\
(72.50)\end{array}$ & $\begin{array}{l}36 \\
(15.0)\end{array}$ & $\cdots$ & $\cdots$ & & $\begin{array}{l}66 \\
(28.0)\end{array}$ & $\begin{array}{l}160 \\
(67.0)\end{array}$ & $\begin{array}{l}240 \\
(100)\end{array}$ & $\begin{array}{l}240 \\
(100)\end{array}$ & $\begin{array}{l}240 \\
(100)\end{array}$ & $\begin{array}{l}240 \\
(100)\end{array}$ & $\begin{array}{l}240 \\
(100)\end{array}$ \\
\hline
\end{tabular}

Overall situation shows that there is a pressing need for fresh water and due to water pollution people are over burdened with expenditure on water. In Pratapa Singaram the annual expenditure is Rs.10,800/-, Enkiryala is Rs. 79,640/-, Surapally is Rs. 63,360/- and Aroor is Rs. 1,69,200/-,. Aroor spent more expenditure on water, followed by Enkiryal, Pratapa Singaram and Surapally. The variation of water expenditure in four villages, they are unable to purchase drinking water but forced to do so. There is no other alternative. Few are purchasing water for cooking purpose also. The cost of water is varying in the sample villages. So there is variation for the same 20 liters in the annual expenditure if compared. The variation is also due to filter stations in Enkariyala and Surapally. The details were given in table Explanation of The details were given in table no:3.

Table 4: Distribution of Household Population According to Health Hazards in Sample Villages

\begin{tabular}{|l|l|l|l|l|l|l|l|l|l|l|}
\hline & $\begin{array}{l}\text { Sample } \\
\text { population }\end{array}$ & $\begin{array}{l}\text { Arthritis } \\
(\%)\end{array}$ & $\begin{array}{l}\text { Skin } \\
\text { Diseases } \\
(\%)\end{array}$ & $\begin{array}{l}\text { Diarrheic } \\
(\%)\end{array}$ & $\begin{array}{l}\text { Stomach } \\
\text { Pain } \\
(\%)\end{array}$ & $\begin{array}{l}\text { Malaria } \\
(\%)\end{array}$ & $\begin{array}{l}\text { Food } \\
\text { poison } \\
(\%)\end{array}$ & $\begin{array}{l}\text { Eye } \\
\text { diseases } \\
(\%)\end{array}$ & $\begin{array}{l}\text { Pediatric } \\
\text { Problems } \\
(\%)\end{array}$ & $\begin{array}{l}\text { Jaundices } \\
(\%)\end{array}$ \\
\hline $\begin{array}{l}\text { Pratapa } \\
\text { sngaram }\end{array}$ & 246 & $\begin{array}{l}169 \\
(68.69)\end{array}$ & $\begin{array}{l}168 \\
(68.29)\end{array}$ & $\begin{array}{l}109 \\
(44.30)\end{array}$ & $\begin{array}{l}119 \\
(48.37)\end{array}$ & $\begin{array}{l}111 \\
(45.12)\end{array}$ & $\begin{array}{l}124 \\
(50.40)\end{array}$ & $\begin{array}{l}36 \\
(14.63)\end{array}$ & $\begin{array}{l}56 \\
(22.76)\end{array}$ & $\begin{array}{l}15 \\
(6.09)\end{array}$ \\
\hline Enkiryal & 460 & $\begin{array}{l}305 \\
(66.30)\end{array}$ & $\begin{array}{l}287 \\
(62.39)\end{array}$ & $\begin{array}{l}196 \\
(42.60)\end{array}$ & $\begin{array}{l}213 \\
(46.30)\end{array}$ & $\begin{array}{l}151 \\
(32.82)\end{array}$ & $\begin{array}{l}164 \\
(35.65)\end{array}$ & $\begin{array}{l}61 \\
(13.26)\end{array}$ & $\begin{array}{l}125 \\
(27.17)\end{array}$ & $\begin{array}{l}24 \\
(5.21)\end{array}$ \\
\hline Surapally & 267 & $\begin{array}{l}180 \\
(68.91)\end{array}$ & $\begin{array}{l}184 \\
(68.91)\end{array}$ & $\begin{array}{l}89 \\
(33.33)\end{array}$ & $\begin{array}{l}158 \\
(53.17)\end{array}$ & $\begin{array}{l}35 \\
(13.10)\end{array}$ & $\begin{array}{l}120 \\
(44.94)\end{array}$ & $\begin{array}{l}34 \\
(12.73)\end{array}$ & $\begin{array}{l}77 \\
(28.83)\end{array}$ & $\begin{array}{l}15 \\
(5.61)\end{array}$ \\
\hline Aroor & 280 & $\begin{array}{l}206 \\
(73.57)\end{array}$ & $\begin{array}{l}171 \\
(61.07)\end{array}$ & $\begin{array}{l}53 \\
(18.92)\end{array}$ & $\begin{array}{l}101 \\
(36.07)\end{array}$ & $\begin{array}{l}32 \\
(11.42)\end{array}$ & $\begin{array}{l}53 \\
(18.92)\end{array}$ & $\begin{array}{l}29 \\
(10.35)\end{array}$ & $\begin{array}{l}52 \\
(18.57)\end{array}$ & $\begin{array}{l}16 \\
(5.71)\end{array}$ \\
\hline Grand & 1253 & $\begin{array}{l}860 \\
(68.64)\end{array}$ & $\begin{array}{l}810 \\
(64.00)\end{array}$ & $\begin{array}{l}447 \\
(35.67)\end{array}$ & $\begin{array}{l}591 \\
(47.17)\end{array}$ & $\begin{array}{l}329 \\
(26.26)\end{array}$ & $\begin{array}{l}461 \\
(36.79)\end{array}$ & $\begin{array}{l}160 \\
(12.77)\end{array}$ & $\begin{array}{l}310 \\
(24.7)\end{array}$ & $\begin{array}{l}70 \\
(5.59)\end{array}$ \\
\hline
\end{tabular}

Source: Field survey conducted on January 2009.

Due to pollution in water, people are suffering from various health hazards irrespective of the caste. But the Forward Castes are in better position than other people. Most of the people were suffering from Arthritis (68.29\%) and Skin diseases (68.29\%). Fifty percent of the sample households were suffering from Diarrheic. Among the other problems, major were Stomach Pain (48.3\%) and Malaria.(45.1\%). The remaining problems identified were pediatric problems and eye diseases. The details of health hazards in Pratap Singaram village were given in table No:4 In Enkirayala Village also majority of the sample households were suffering from Arthritis (66.3\%) and Skin Diseases (62.3\%) food poison was less (35.6\%) among the sample households when compared to Pratap Singaram village. The sample households were suffering from Stomach Pain (46.3\%) and Diarrheic 42.6\%). The other problems were eye diseases (13.6\%), pediatric problems $(27.1 \%)$ and Jaundices $(5.2 \%)$. The caste wise distribution of health hazards in Enkirayala village. The health hazards were similar in Surapally village like the above villages. Arthritis (68.9\%) and Skin diseases (68.9\%)., Stomach Pain was more in the village (53.1\%). All these problems are due to the pollutants and the differences in percentages are due to the variation in percentage of pollutants causing the hazard in a particular village. Food poison was another major health hazard $44.9 \%$ ). The caste wise distribution of health hazards of Surapally village. In Aroor village Arthritis was identified more (73.4\%) at the time of survey. This was followed by Skin diseases $(61.0 \%)$ Next come Stomach pain (36.0\%). All the other hazards were below twenty percent. Jaundices $(5.7 \%)$ were less 
among all the health hazards. Large numbers of people in the sample villages have complained about arthritis, as many as 68.64 percent have complained about acute joint pains. While it is the most common among old people, even young people have reported severe joint pains. Every person suffering from joint pains is observed to consume painkillers like bruffen, naiacin, Nice, diclofenac sodium etc every day. Some patients developed serious side effects of overdoses of pain killers that cause nervousness. Some households said even children are complaining about the same. Second, skin diseases are reportedly quite high in incidence and almost 64.00 percent of the respondents have skin diseases. Those who get into the village tanks, like fishermen and washer men are affected acutely by skin diseases that are diagnosed as Rabson's disease. This causes severe ulcers on the skin that would become infectious if not treated by strong antibiotics. It partially prevents from attending the regular job work. 36.79 percentage of the sample population suffered from food poison, and 35.67 percent of the sample populations are affected by diarrheic and 26.26 percent reportedly suffered from malaria, as mosquitoes swarm the villages in the night in all seasons. The other problems reported were severe eye diseases, pediatric problems and jaundices. Details are given in table no:4.

Table 5: Water Related Health Problems and Economic Problems Among the Selected H.H's.

\begin{tabular}{|c|c|c|c|c|c|c|c|c|c|c|c|c|c|c|c|c|}
\hline \multirow[b]{2}{*}{ Problem* } & \multirow{2}{*}{$\begin{array}{l}\text { Tot } \\
\text { al } \\
\text { No. } \\
\text { sa } \\
\text { mp } \\
\text { le } \\
\text { pop } \\
\text { ulat } \\
\text { ion }\end{array}$} & \multicolumn{3}{|l|}{ Sex } & \multicolumn{3}{|c|}{$\begin{array}{l}\text { No of } \\
\text { days sick } \\
\text { (avg. } \\
\text { Monthly) }\end{array}$} & \multicolumn{3}{|c|}{$\begin{array}{l}\text { Ne of days } \\
\text { unable to } \\
\text { work } \\
\text { (Monthly) }\end{array}$} & \multicolumn{3}{|c|}{$\begin{array}{l}\text { Ne of visits to } \\
\text { doctor } \\
\text { (monthly) }\end{array}$} & \multicolumn{3}{|c|}{$\begin{array}{l}\text { Spent on medicine } \\
\text { (Axgeg monthly) }\end{array}$} \\
\hline & & $\mathrm{M}$ & F & $\mathrm{C}$ & $\mathrm{M}$ & $F$ & $\mathrm{C}$ & $\mathrm{M}$ & $F$ & $\mathrm{C}$ & $\mathrm{M}$ & $F$ & $\mathrm{C}$ & $\mathrm{M}$ & $F$ & $\mathrm{C}$ \\
\hline $\begin{array}{l}\text { Skin } \\
\text { allergies }\end{array}$ & 810 & $\begin{array}{l}48 \\
0\end{array}$ & 300 & 30 & 3 & 5 & 9 & 2 & 3 & 4 & 3 & 3 & 4 & 105 & 130 & 142 \\
\hline Joint pains & 860 & $\begin{array}{l}43 \\
9\end{array}$ & 375 & 46 & 5 & 5 & 2 & 2 & 2 & 3 & 2 & 3 & 4 & 120 & 135 & 135 \\
\hline $\begin{array}{l}\text { Stomach } \\
\text { pains }\end{array}$ & 591 & $\begin{array}{l}29 \\
0\end{array}$ & 257 & 44 & 2 & 5 & 3 & 1 & 3 & 4 & 1 & 2 & 2 & 50 & 60 & 60 \\
\hline Diaheria & 447 & $\begin{array}{l}22 \\
6\end{array}$ & 193 & 28 & 4 & 3 & 7 & 2 & 3 & 4 & 2 & 3 & 5 & 100 & 100 & 150 \\
\hline Eye dieseas & 160 & 98 & 42 & 20 & 7 & 7 & 7 & 7 & 7 & 7 & 2 & 2 & 2 & 50 & 50 & 50 \\
\hline $\begin{array}{l}\text { Pediatric } \\
\text { problems }\end{array}$ & 310 & & & $\begin{array}{l}31 \\
0\end{array}$ & & & $\begin{array}{l}1 \\
0\end{array}$ & & & 10 & & & 3 & & & 150 \\
\hline Malaria & 329 & $\begin{array}{l}15 \\
0\end{array}$ & 162 & 37 & 8 & 8 & 8 & 10 & $\begin{array}{l}1 \\
0\end{array}$ & 10 & 2 & 2 & 2 & 75 & 75 & 75 \\
\hline $\begin{array}{l}\text { Food } \\
\text { poision }\end{array}$ & 461 & $\begin{array}{l}19 \\
6\end{array}$ & 209 & 56 & 2 & 3 & 3 & 3 & 4 & 4 & 1 & 1 & 1 & 25 & 25 & 25 \\
\hline
\end{tabular}

Source: Pratapa singaram, Enkiryala, Surapally,Arooru, house hold field survey. conducted on January 2009. *Excluding jaundice

The details of the affects of the health hazards in terms of number of days sick, number of days of work and average, money spent on the health hazards shows that the families are facing problems financially The average monthly medical expenditure for skin allergies was Rs.105/-for male, for a female Rs.130/-, and children's was Rs.142/-. The average monthly medical expenditure for Joints pains was Rs.120/-for male, for a female Rs.135/-, and children's was Rs.135/-. The average monthly medical expenditure for stomach pain was Rs.50/-for male, for a female Rs.60/-, and children's was Rs.60/-. The average monthly medical expenditure for Diaherriac was Rs.100/-for male, for a female Rs.100/-, and children's was Rs150/-. The average monthly medical expenditure for Eye dieseas was Rs.50/-for male, for a female Rs.50/-, and childrens was Rs.50/-. The average monthly medical expenditure for pediatric problems was Rs.150/-.The average monthly medical expenditure for Malaria was Rs.75/-for male, for a female Rs.65/-, and childrens was Rs.60/-.The average monthly medical expenditure for food poision was Rs.105/-for male, for a female Rs.25/-, and childrens was Rs.25/-. . They have to spend more money for treatment and there is income loss due to sickness. These are averages for one time. Since the pollution is continuing, how many times it repeats depend on the extent of pollution and the physical resistance of the families. In several households it was observed that the expenditure for pain killers was more than Rs. 300/- per month. For a male laborer, the income loss for one day will be Rs.150/-, for a female, Rs.100/- and for a child, ranging from Rs.50/- to 80/-. Jaundice is excluded from the table because the treatment will be more that one month and generally people will go for Unani or Aurvedic for treatment. Here medical expenses will be less than Rs.100/- but for recovery it takes more than one month and the income loss will be more. Details are given in table no: 5 
Musi River Pollution Its Impact On Health And Economic Conditions Of Down Stream Villages-A

Table 6: Health Expenditure in Selected Villages (Rs.)

\begin{tabular}{|l|l|l|l|l|}
\hline Name of Disease & Male & Female & Children & Total \\
\hline Skin allergies & 50,400 & 39,000 & 4,260 & 93,660 \\
\hline Joint Pains & 52,680 & 50,625 & 6,210 & $1,09,515$ \\
\hline Stomach Pains & 29,550 & 17,400 & 2,640 & 49,590 \\
\hline Diarrheic & 22,600 & 19,300 & 4,200 & 46,100 \\
\hline Eye Disease & 4,900 & 2,100 & 1,000 & 8,000 \\
\hline Pediatric & -- & --- & 46,500 & 46,500 \\
\hline Malaria & 11,250 & 12,150 & 2,775 & 26,175 \\
\hline Food Poisons & 4,900 & 5,225 & 1,400 & 11,525 \\
\hline Grand Total & $1,76,280$ & $1,45,800$ & 68,985 & $3,91,065$ \\
\hline
\end{tabular}

Source: Field Survey conducted on January 2009.

Given the details of the affected of the health hazards in terms of value in rupees. They have to spend more money for treatment and there is loss of income due to sickness. In several households it was observed that the expenditure for Joint pains was more that is Rs.1,09515/- , then followed by Skin allergies is .93,660/- , very low expenditure spend on Eye disease Rs.8,000/- . The pollution is drastically effected on the $\mathrm{n}$ health, they loosing of their health only 10 per cent of sample household medical expenditure is .3,91,065/-, it is convert into total household the money burden in crores of rupees. The details are given in the table no:6.

\section{One way ANNOVA TEST}

\begin{tabular}{|l|l|l|l|l|l|l|}
\hline & $\boldsymbol{N}$ & Mean & Std.Deviation & Std.Error & Minimum & Mximum \\
\hline Male & 7 & 25182.86 & 20143.87145 & 7613.668 & 4900.00 & 52680.00 \\
\hline Female & 7 & 20828.57 & 17802.94000 & 6728.879 & 2100.00 & 50625.00 \\
\hline Children & 8 & 3623.1250 & 15396.50075 & 5443.485 & 1000.00 & 46500.00 \\
\hline total & 22 & 17775.68 & 18406.96823 & 39274.379 & 1000.00 & 52680.00 \\
\hline
\end{tabular}

ANOVA Expenditure

\begin{tabular}{|l|l|l|l|l|l|}
\hline & Sum of squares & Df & Mean square & F & Sig \\
\hline Between Groups & 1119459039.326 & 2 & 559729519.7 & 1.774 & .197 \\
\hline Within groups & 5995687025.447 & 19 & 315562475.0 & & \\
\hline Total & 7115146064.773 & 21 & & & \\
\hline
\end{tabular}

Table 7: Impact of Pollution on Live Stock in the Sample Villages

\begin{tabular}{|l|l|l|l|l|l|l|l|}
\hline \multirow{2}{*}{$\begin{array}{l}\text { Type of } \\
\text { Cattle }\end{array}$} & \multirow{2}{*}{$\begin{array}{l}\text { No. of } \\
\text { cattle }\end{array}$} & $\begin{array}{l}\text { No of } \\
\text { Affected. }\end{array}$ & \multicolumn{2}{|l|}{ No. of cattle died } & \multicolumn{2}{|l|}{$\begin{array}{l}\text { Milk production } \\
\text { (ltr) }\end{array}$} & Medical \\
\cline { 3 - 8 } & & & $\begin{array}{l}\text { Value } \\
\text { Rs. }\end{array}$ & $\begin{array}{l}\text { Last 5 } \\
\text { years }\end{array}$ & Present & Expenditure \\
\hline Buffaloes & 399 & $\begin{array}{l}103 \\
(25.81)\end{array}$ & 19 & 1.61 .500 & 3.2 & 2.7 & 630 \\
\hline Ox & 75 & $\begin{array}{l}16 \\
(21.33)\end{array}$ & 6 & 49.200 & - & - & 540 \\
\hline Cow & 22 & $\begin{array}{l}6 \\
(27.27)\end{array}$ & 1 & 3.950 & 3 & 1.6 & 300 \\
\hline Goat & 434 & $\begin{array}{l}187 \\
(43.08)\end{array}$ & 151 & 3.02 .000 & - & - & 800 \\
\hline Sheep & 1012 & $\begin{array}{l}401 \\
(39.62)\end{array}$ & 263 & 3.41 .900 & - & - & 810 \\
\hline Total & 1942 & $\begin{array}{l}713 \\
(36.71)\end{array}$ & 440 & 8.58 .550 & & & 3080 \\
\hline
\end{tabular}

Source: Field Survey conducted on January 2009.

Along with human beings, the livestock will also be affected by pollution. Many cattle died due to pollution and the milk production is also significantly affected. The medical expenses became extra burden to the respondents. Out of the total livestock, the data shows that Goat and Sheep died mostly. Even among the affected, the Goat and Sheep are more in number. The value of cattle lost is also increasing and crossing lakhs. 
Musi River Pollution Its Impact On Health And Economic Conditions Of Down Stream Villages-A

Buffaloes was 19 died and 103 affected, out of 399,the value of died Buffaloes was Rs. 1,61,500/-, 6 ox was died the value of them was Rs.49,200/-, cow are 1 died the value was Rs.3,950/-, goats were 151 died and 187 was affected out of 434, the died goats value in terms of rupees was 3,02,000/-, and sheep population are also died , the value was Rs. 3,41,900/-. The annual medical expenditure on buffaloes was Rs.630/-, ox was Rs.540/-, cow was Rs.300/-, goat was Rs.800/-, and Sheep population on Rs.810/-. This also burdens on the respondents. And the Milk Production also decreases from the last five years, buffalo's milk production decline from 3.2 liters to 2.7 liters. Veterinary doctors says that the most of cases are abortions, and most of the disease are comes from the polluted water. This also burdens economically the respondents and affordability also decreases among the people to purchase livestock. Hence there is need to search for alternatives. This shows the need for improvement of veterinary services and control of pollution in the field area. The details were given table no7 .

* Chi-square df significance value $40.1578 \quad 4.0000 \quad 0.0000$

* Conclusion: There is a significance difference. No of effected and No of not effected. This significance values show that the variance between the affected live stock population and non-affected live stock population, in the selected villages.

Table 8: Village Wise Fish-Catch and Value in the Sample Villages

\begin{tabular}{|c|c|c|c|c|c|c|c|c|c|}
\hline \multirow[b]{2}{*}{ Fishing } & \multicolumn{3}{|c|}{ Enkirayala } & \multicolumn{3}{|l|}{ Surapaslly. } & \multicolumn{3}{|l|}{ Aroon } \\
\hline & $\begin{array}{l}1990- \\
95\end{array}$ & $\begin{array}{l}1996- \\
2000\end{array}$ & $\begin{array}{l}2001- \\
2006\end{array}$ & $1990-95$ & $\begin{array}{l}1996- \\
2000\end{array}$ & $\begin{array}{l}2001- \\
2006\end{array}$ & $1990-95$ & $\begin{array}{l}1996- \\
2000\end{array}$ & $\begin{array}{l}2001- \\
2006\end{array}$ \\
\hline Weekly(Kgs) & 8,000 & 6000 & 4000 & 3,000 & 2,500 & 2.2 & 6,000 & 5,200 & 5,000 \\
\hline $\begin{array}{l}\text { Annual fish catch } \\
\text { (Axg } \quad 10 \\
\text { months)Kgs }\end{array}$ & $\begin{array}{l}3,20,00 \\
0\end{array}$ & $2,40,000$ & $1,60,000$ & $1,20,000$ & $1,00,000$ & 88,000 & 24,000 & 20,800 & 20,000 \\
\hline $\begin{array}{l}\text { Annual Gross } \\
\text { Income (Rs.) }\end{array}$ & $\begin{array}{l}32,00,0 \\
00\end{array}$ & $24,00,000$ & $16,00,000$ & $12,00,000$ & $10,00,000$ & $8,80,000$ & $24,00,000$ & $20,80,000$ & $20,00,000$ \\
\hline $\begin{array}{l}\text { Annual Investment } \\
\text { (Rs) }\end{array}$ & $\begin{array}{l}1,00,00 \\
0\end{array}$ & $2,00,000$ & $2,50,000$ & 80,000 & $1,00,000$ & $1,30,000$ & $3,00,000$ & $3,50,000$ & $3,50,000$ \\
\hline $\begin{array}{ll}\text { Annual } & \text { Net } \\
\text { Income(Rs.) } & \\
\end{array}$ & $\begin{array}{l}31,00,0 \\
00\end{array}$ & $22,00,000$ & $13,50,000$ & $11,20,000$ & $9,00,000$ & $7,50,000$ & $21,00,000$ & $17,30,000$ & $16,50,000$ \\
\hline $\begin{array}{l}\text { Net loss Compare } \\
\text { to } \\
\text { (Rs.)1998-95 }\end{array}$ & - & $9,00,000$ & $17,50,000$ & - & $2,02,000$ & $3,70,000$ & - & $3,70,000$ & $4,50,000$ \\
\hline
\end{tabular}

Source: Enchorial, Surapally, Aroor Industrial fishermen co-operative society December 2008)

In Pratap Singaram there are no fisher men. Because fishes are not live in this area, it is highly polluted areas. The data shows that there was gradual decline in the quantum of fish catch and decrease of annual income from fish catch. Interestingly the investments were increasing year after year. When compared with quantum of catch and profit, the losses are more. The net losses show the non viability of the activity and income loss to fisher men. Relatively, Enkirayala is badly affected in this business. The net loss was very high in Enkirayala when compared to other sample villages where the loss during 2001 to 2006 was Rs, 17, 50,000/-. The net loss was in Surapally village where the loss during 2001 to 2006 was Rs, 3,70,000/-.The net loss in Arooru villages was during 2001 to 2006 was Rs, 4,50,000/- The details were given in table No8.

Table 9: Impact of Water Pollution on Traditional Occupation for the Sample Villages

\begin{tabular}{|l|l|l|}
\hline $\begin{array}{l}\text { Traditional } \\
\text { Occupations }\end{array}$ & Total selected population & $\begin{array}{l}\text { No. of people } \\
\text { Affected }\end{array}$ \\
\hline Washer men & 145 & $106(73.10)$ \\
\hline Fisher men & 195 & $174(89.23)$ \\
\hline Yadavas & 155 & $89(57.41)$ \\
\hline Toddy Tapper & 115 & $29(25.21)$ \\
\hline Gold smith & 15 & $2(13.33)$ \\
\hline Pottery & 10 & $6(60)$ \\
\hline Weavers & 08 & $1(12.5)$ \\
\hline Total & 643 & $407(63.29)$ \\
\hline
\end{tabular}

Source: Field Survey conducted on January 2009.

The pollution has affected the traditional occupations very badly. The washer men stopped washing their clothes because the people wearing them are getting skin allergies. The washer men were also getting skin allergies because they have to work with the polluted water of Musi. Earlier, they have good income from the surrounding villages. Now they are becoming daily laborers by leaving the occupation completely. Even though 
much detergent is not necessary for washing the clothes, foul smell is emanating from the clothes after drying them. Fishes died due to pollution and the fisher men lost their occupation. Due to pollution, weed is growing in the tanks and the levels of BOD and COD are coming down in the tanks due to which, fish are dieing. Even survived, the fish are less in weight when compared to the weights of 1995 and the relative income has substantially decreased for the fisher men. The fisher men are getting skin allergies due to entering into the polluted water. The occupation is becoming extinct in the sample villages. Even for removing the weed from the tank, it costs around one lakh rupees which is beyond the capacity of the fishermen to afford and remove the weed. The cattle like Buffaloes, sheep and goat were getting diseases and dieing due to polluted water. So, traditional occupation of Yadavas was affected and many people were leaving the occupation. Due to pollution of water, the people who consume taddy from the trees in and around the Musi river are getting diarrhea. So, the business of the surrounding Toddy Tappers was affected and the people have to leave their occupation. The silver items were becoming black even if they were polished within a short span of time. But the impact of pollution is less on gold smiths. Due to the water pollution, the soil is getting affected and due to the poor quality of soil, the potters are unable to make the pots and leaving their occupation. The dyes are affected due to polluted water and the colors are fading due to which the weavers have to stop their activity and search for alternatives. The overall picture shows that water pollution has affected the traditional occupations and livelihoods of majority of the people living in the sample villages. The details are given in the table no:9.

* Chi-square df significance value 161.58896 .00000

* conclusion: There is a significance difference

\section{Summary and Conclusion}

In this article we try to measure impact of pollution of Musi River on selected household. It has been found that the pollution has been given rise four major problems namely, pollution of drinking wad irrigation water, large incidence of diseases like arthritis, diarrheic, skin allergies, stomach pain, malaria, food poison, eye diseases, pediatric problems and jaundices diseases suffered by the people, impact on the live stock and cropping pattern in sample villages. Studies conducted by I.P.M. Institute of Preventive Medicine, Hyderabad, Andhra Pradesh. Have certified that water highly polluted containing BOD, COD , TDS, TSS, Nitrates, phosphors, Alkalinity, Total Hardness, $\mathrm{Ph}$, chloride, Floride, etc.., this has force people to buy water from outside, resulting extra burden on their family budget. Because of large incidence of diseases of cause by pollution medical expenses have also increased, fish population has disappear in Pratapa Singaram and Enkiryal, in other villages availability is very much less. The Musi canal water those it available and abundant highly polluted, it is found that the paddy, vegetables grown in the area highly contaminated, the water quality for non-farm activities are also adversely affect because of polluted affect, the incidence of poultry diseases increases, and milk production is also affected from the cattle population. Similarly it is found that the traditional occupations like, those of washer men, fishermen, weavers, pot makers, and toddy tappers are adversely affected. At the same time it is equally important initiative urgent measures in the downstream villages for providing relief to the victims of pollution. At the village level itself it is necessary to identify the sources of pollution and provide remedial measures. It is necessary to give top priority provision of safe drinking water and improving the medical facilities for the affected people, Similarly measures have to initiative macro and micro level to improve the soil conditions, the quality of irrigation and drinking water provide for growth of lively hood in the non-farming sectors like poultry, dairy, related village level industries.

\section{References}

[1] Central Pollution Control Board (2002) “PARIVESH” news Letter, New Delhi.

[2] Hodge, Ian (1995): Environmental Economics: Industrial Incentives and Publications. Mac Maillian Press, London.

[3] Murthy,M.N, A. James, and Smita Misra (1999-2000): Economics of Water Pollution: The Indian Experience, Oxford University Press, New Delhi.

[4] Murthy,M.N.(1995)"Environmental Regulation in the Developing World: A Case Study of India" Review of European Community and International Environmental Law,Vol.4 pp330-337.

[5] Pullaiah cheepi (2009) "Impact of pollution of Musi River Water in Down Stream Villages-A Study". Unpublished Ph.D Thesis submitted to Department of Economics, Osmania University Hyderabad India.

[6] Van der Hoek, Mehmood UI Hassan Jeroen H.J.Ensink, Sabiena Feenstra, Liqa Raschid-Sally,Saffraz Munir, Rizwan Aslam, Nazim Ali, Raheela Hussain and Yutaka Matsuno, (2002). Urban Wasterwater: A Valuable Resource for Agriculture- A Case Study from Haroonabad, Pakistan. IWMI -Research Report 63,

[7] Colombo, Sri Lanka.

[8] WHO(1971), ISI(1983) and CPHEEO 


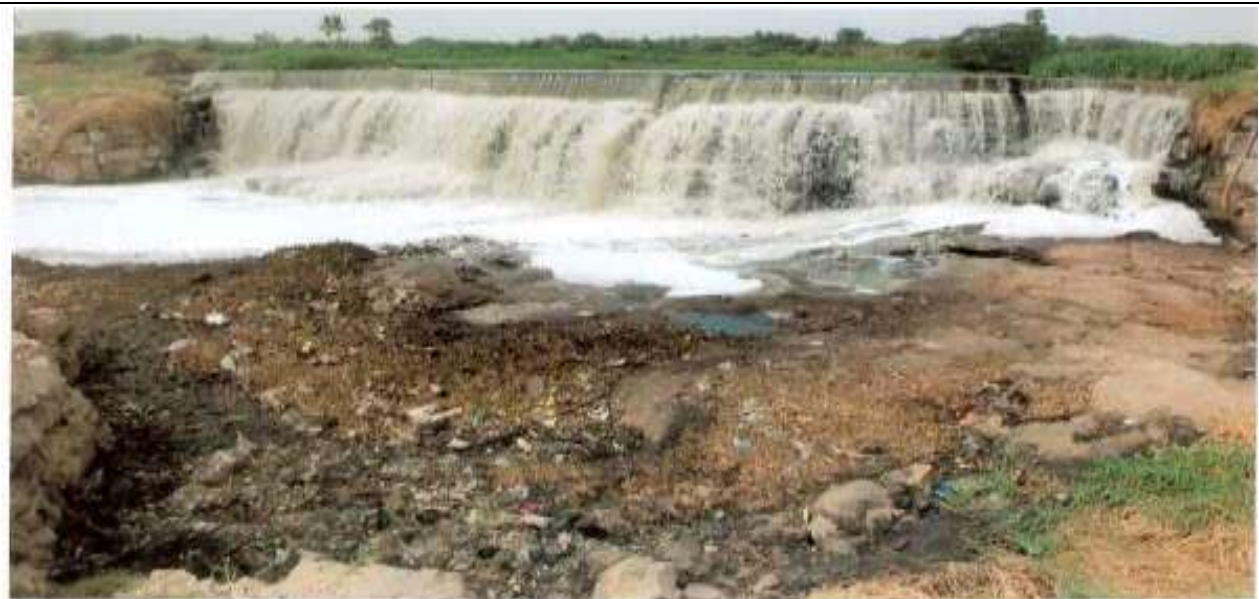

Musi River Water at Narayana Reddy Katwa, this water is used for all types of crops.

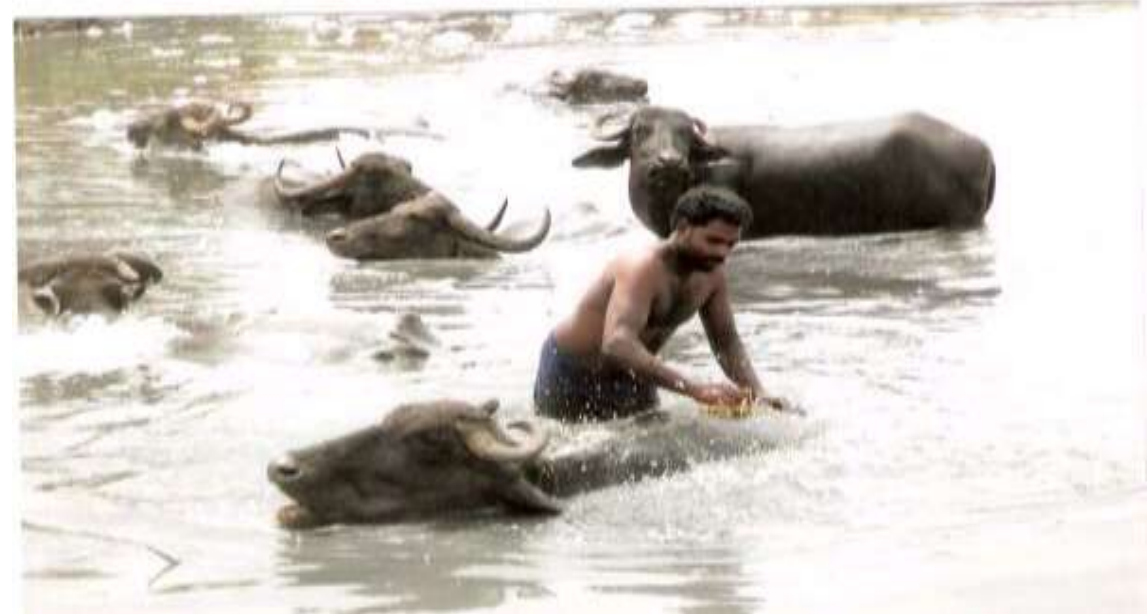

Buffaloes Are Washed With the Polluted Water, this water is caused to the skin diseases for any biotic at Narayana Reddy Katwa

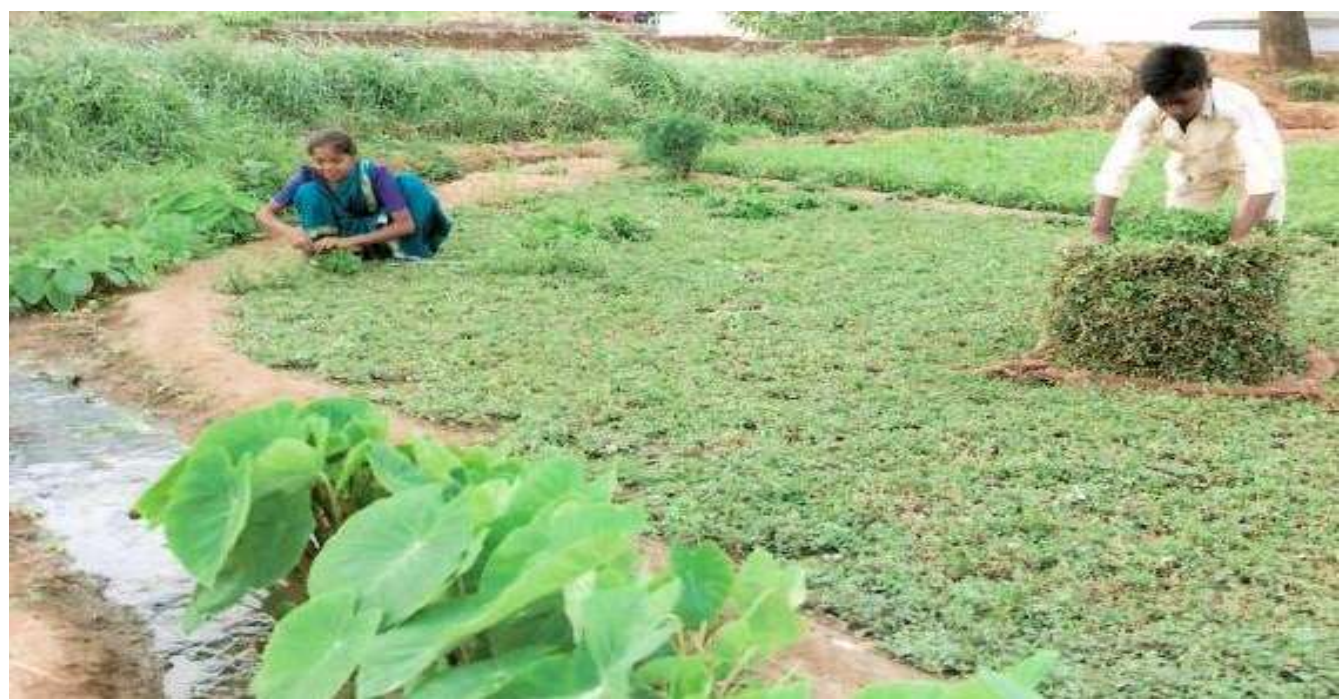

Leaf Vegetables Are Producing through the Polluted Waste Water Between The Area Of Pratapa Aram And Peerjadi Guda, these vegetables are supplied to city markets. 


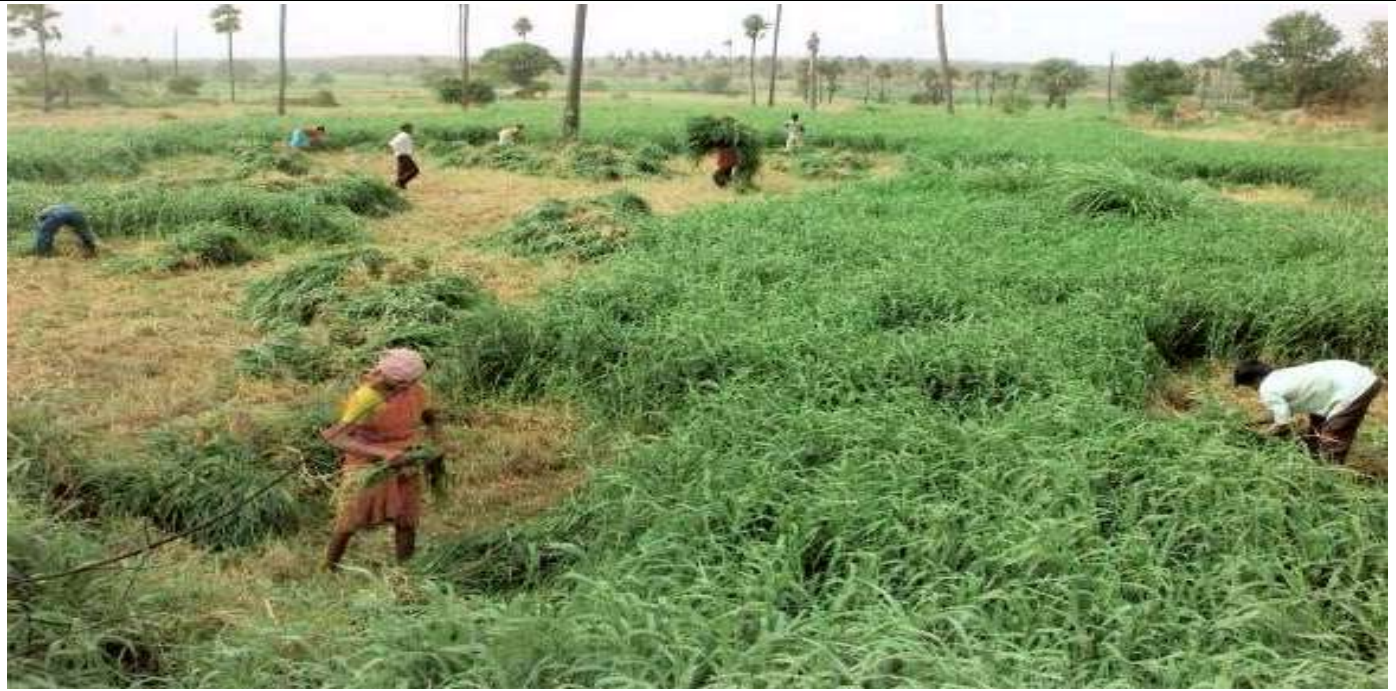

Polluted water with para grass cultivation At Pratapa singaram, this grass is grown without using of any fertilizers

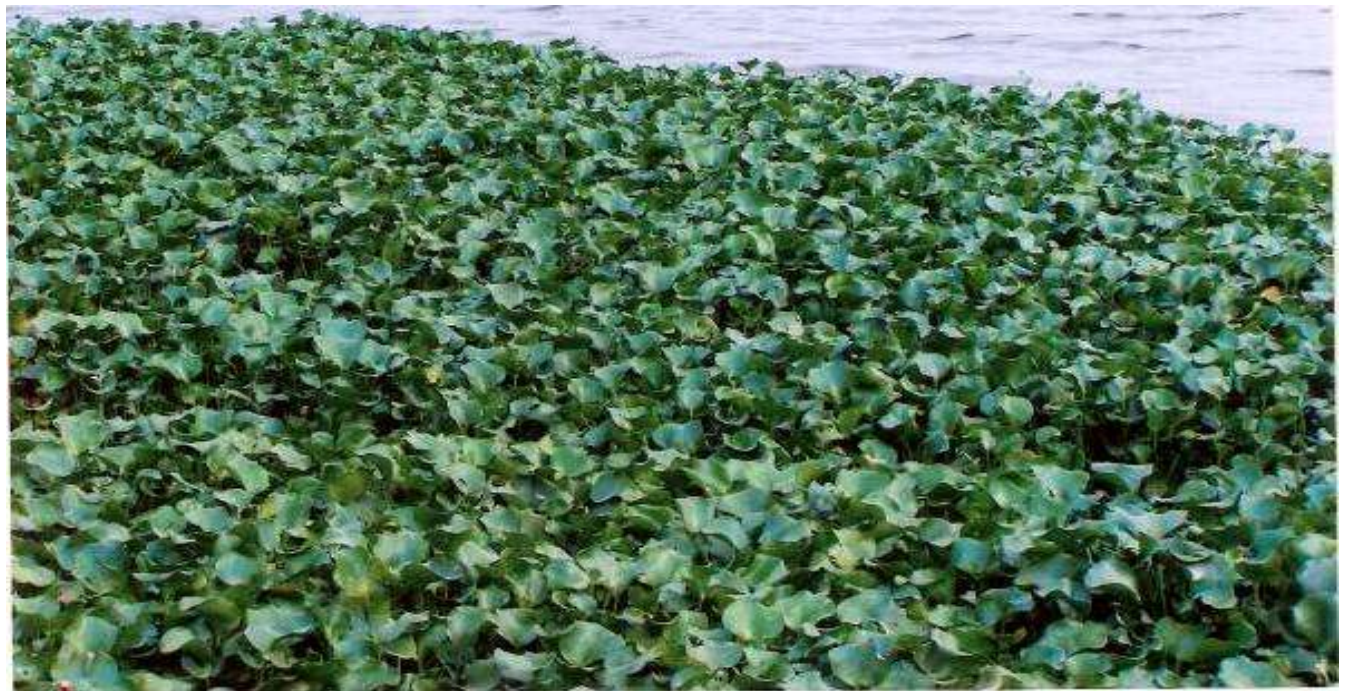

Enkiryal Tank Due To Pollution Water Gurrapu Dekka Grown Rapidly (Weed)

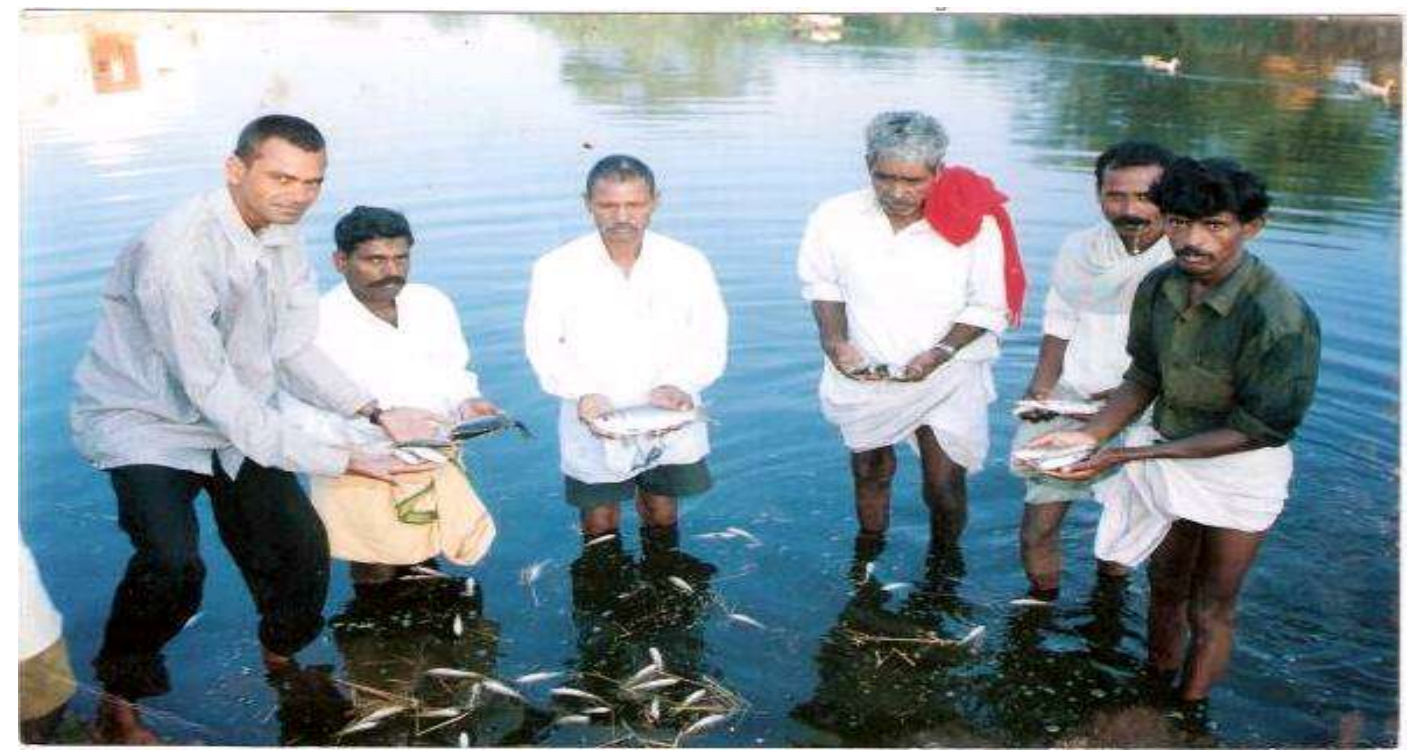

Fish Population Were Died Due to the Polluted Water in Enkiryala Tank 